FOLIA HISTORICA CRACOVIENSIA, 22: 2016, s. 303-328

DOI: http://dx.doi.org/10.15633/fhc. 2083

Adam Organisty

Akademia Sztuk Pięrnych w Krakowie

\title{
Mistyka hiszpańska na gruncie malarstwa Akademii Sztuk Pięknych w Krakowie przełomu XX i XXI wieku
}

Przed dekadą Krystyna Czerni, przyglądając się twórczości Janusza Matuszewskiego, pisała o istnieniu nieformalnego „bractwa czcicieli manieryzmu i baroku”, działającego, jej zdaniem, w krakowskiej Akademii. Artystów, zauważała, łączy „ «teologia ciemności» św. Jana od Krzyża, [...] «gorąca, święta ciemność XVII-wiecznych tenebrystów»" szewskiego określała zaś współczesnym „barokizmem”2. Z dzisiejszej perspektywy spostrzeżenia te odnieść można również do innych pedagogów Wydziału Malarstwa Akademii Sztuk Pięknych w Krakowie - Grzegorza Bednarskiego, Katarzyny Makieły-Organisty, Mirosława Sikorskiego, Edyty Sobieraj, Zbigniewa Sprychy czy Wojciecha Szybista. Znamienne, że genezę stylową ich obrazów wywodzić trzeba z zupełnie różnych krakowskich tradycji artystycznych - od koloryzmu, poprzez neoekspresjonizm, aż po metaforyczną figurację. Przyglądając się analizowanym poniżej pracom, należy pamiętać, że nie tworzą ich malarze,

K. Czerni, Popiół i diament, [w:] Janusz Matuszewski, katalog wystawy, Galeria u Jezuitów, Poznań 2004, nlb. [s. 7]; K. Czerni, „My wszyscy, którzy rośliśmy w miastach Baroku...” - czyli o fascynacji barokiem współczesnych malarzy krakowskich, [w:] Barok i barokizacja. Materiały sesji Oddziału Krakowskiego Stowarzyszenia Historyków Sztuki Kraków 3-4 XII 2004, red. K. Brzezina, J. Wolańska, Kraków 2007 (Ars Vetus et Nova, red. W. Bałus, t. 28), s. 373.

2 Zob. M. Kitowska-Łysiak, Barokista, [w:] Janusz Matuszewski. Malarstwo, folder wystawy, oprac. A. Orłowska, Galeria Współczesnej Sztuki Sakralnej „Dom Praczki” w Kielcach, maj-lipiec 2012, Kielce 2012, nlb. [s. 7]: „Jeśli o niektórych artystach mówimy per manierysta czy klasycysta, to może innych moglibyśmy nazwać «barokistami». Ten neologizm przyszedł mi na myśl podczas oglądania ostatnich prac Janusza Matuszewskiego”. Por. A. Organisty, „Na przebłaganie za grzechy nasze...” O malarstwie religijnym Grzegorza Bednarskiego i Janusza Matuszewskiego, „Ethos. Kwartalnik Instytutu Jana Pawła II KUL - Lublin i Fundacji Jana Pawła II - Rzym” (2014) nr 105, s. $239-253$. 
których jednoczyć miałby manifest artystyczny. Nie prezentują oni swoich prac wspólnie i nie powołują się na jeden program. Omawianych artystów łączy jedno miejsce i czas - Akademia przełomu xx i xxI wieku. Na przestrzeni ostatnich dwóch dekad skonstatować można istnienie zjawiska artystycznego w środowisku krakowskiej uczelni, w którym wyraźnie mamy do czynienia ze wspomnianą inspiracją barokiem, i to zwłaszcza hiszpańskim malarstwem Złotego Wieku. Odwołaniom do dzieł mistrzów Półwyspu Iberyjskiego towarzyszyć mogą odniesienia do pism karmelitańskich czy jezuickich mistyków, ponieważ poszczególni malarze bezpośrednio je przytaczają. O ile zestawienie wybranych płócien krakowskich z nowożytnym malarstwem będzie od strony formalnej i niejednokrotnie tematycznej kwestią oczywistą, o tyle znacznie trudniejszym zadaniem będzie próba postawienia pytania o możliwość obrazowania „teologii mistycznej”, opisanej przez św. Teresę od Jezusa, św. Jana od Krzyża czy św. Ignacego Loyolę.

Dla Zbigniewa Sprychy obrazy Velázqueza były ważne jeszcze od czasów licealnych. Co ciekawe, malarz nigdy nie był w Hiszpanii.

Skarżyński też nie był w Hiszpanii - podkreśla Sprycha - i przygotował znakomitą scenografię do Pamiętnika znalezionego w Saragossie. Młody Bizet, którego noga nigdy nie stanęła na Półwyspie Iberyjskim, również stworzył w Carmen wizję muzyki hiszpańskiej. Nosi się pewien obraz w sobie i to dzięki artystom oraz ich sztuce ${ }^{3}$.

3 Cyt. za: A. Organisty, O infantkach w twórczości malarskiej Zbigniewa Sprychy, [w:] [publikacja na temat polskich przedstawień Infantki Małgorzaty], red. J. Malinowski (Studia o Sztuce Nowoczesnej) [w druku]. Por. Sprycha, Galeria Akademii, ul. Bracka 4, Kraków, styczeń-luty 1987, b.r., b.m.w.; A. Z. Nowakowski, [wstęp], [w:] Sprycha. Malarstwo, katalog wystawy, Biuro Wystaw Artystycznych w Krakowie, czerwiec 1990, Kraków 1990, nlb. [s. 3]; A. Brincken, [wprowadzenie], [w:] Zbigniew Sprycha, katalog wystawy, Dom Kultury Podgórze - Centrum Sztuki Współczesnej „Solvay”, Kraków b.r. [2001], nlb. [s. 3]; Don Kichot. Wspótczesna próba interpretacji, katalog wystawy, Galeria Dominika Rostworowskiego, Kraków, 5-17.11.2004, Kraków 2004, nlb. [s. 42-43]; K. Czerni, Zielona Infantka albo Mistrz i Małgorzata, [w:] Zbigniew Sprycha, katalog wystawy, Galeria u Jezuitów, Poznań 2004, nlb. [s. 7-11]; Zbigniew Sprycha. Malarstwo, katalog wystawy, Galeria Krypta u Pijarów, grudzień 2006, Kraków 2006, nlb. [s. 5]; S. Tabisz, Nieobecność infantki. Nowe obrazy Zbigniewa Sprychy, [w:] Zbigniew Sprycha. Wystawa malarstwa, katalog wystawy, Salon Antykwaryczny „Nautilus”, Kraków, 10.06. - 30.06.2006, Kraków 2006, s. 3; K. Czerni, „My wszyscy, którzy rośliśmy w miastach Baroku...”..., dz. cyt., s. 377-38o; G. Bednarski, Prawo rzeczowości. Poetyckie malarstwo Zbigniewa Sprychy, „Wiadomości Akademii Sztuk Pięknych w Krako- 
W kontekście naszych rozważań kreowany przez Sprychę świat infantek czy Don Kichota nie będzie aż tak istotny. Uwagę przykuwa natomiast jego cykl Pracownia, w którym widać nie tylko oczarowanie dekoracyjnymi właściwościami fakturalnego koloryzmu (malarz do dzisiaj ceni spotkanie z nauczycielem, Juliuszem Joniakiem). Ciemna tonacja nadaje tym dość znacznych rozmiarów kompozycjom medytacyjny charakter. Przedstawiają one puste przestrzenie, w których wybrane motywy nabierają symbolicznego znaczenia - artysta wyróżnia je karminem lub ultramaryną. $\mathrm{W}$ imaginacyjnym, mrocznym wnętrzu $\mathrm{z}$ roku 2001 rozpoznajemy kamienne płyty, przypominające nagrobne stele (il. 1). Światło, mające swoje źródło w głębi kompozycji, subtelnie zespala poszczególne partie obrazu w jedną całość. Ważny jest dla niego w trakcie malowania „stan skupienia", jak mówi, odnosząc się jednocześnie do zbliżonego stylowo malarstwa Edyty Sobieraj. U obu malarzy puste i mroczne wnętrza, ujmują zobrazowaniem melancholijnego stanu, wyobrażenia oschłości i utraty. Stawiają widza wobec pytania o umiejętność niemal pustelniczego przebywania w tych wnętrzach, w takim stanie. Samotność, jak powiada Sobieraj, jest dla niej „w ogóle warunkiem tworzenia. Zamykam się we własnym świecie, a tylko w ten sposób mogę coś o sobie opowiedzieć. Zamknięcie to jednak nie oznacza braku otwarcia na to co jest na zewnątrz. Ważne jest przeżywanie rzeczywistości, przełożenie jej na język malarski”" . Przed kilkoma laty nad fenomenem twórczości Sobieraj zastanawiał się Adam Brincken, pisząc:

Jeśli ktoś przez ponad dziesięć lat upiera się przy swoim malując kilkadziesiąt, kilkaset płócien, a te pod jakimś względem wydają się być bardzo do siebie podobne, wyprowadzając następne z poprzednich - i rozpoznawalny zdaje się ich ton oraz materia przy czym, nie przykuwają uwagi pośpieszną narracją formy, nie są lekkie ani nazbyt miłe, więcej w nich mroku niż światła, a mimo to „istnieją” w pamięci i świadomości wielu, którzy je oglądali, to zapewne są ,jakieś" ku temu powody ${ }^{5}$.

wie" 49 (2010) kwiecień, s. 50-51; A. Organisty, Prace artystów z Wydziału Malarstwa Akademii Sztuk Pięknych w Krakowie, [w:] Akademia Sztuk Pięknych im. Jana Matejki w Krakowie. Wydział Malarstwa 2010 / Jan Matejko Academy of Fine Arts in Krakow. The Faculty of Painting 2010, red. Z. Bajek i in., Kraków b.r. [2011], s. 30-32, 272-277.

4 Opowieść o rzeczach niepotrzebnych. Z Edytą Sobieraj rozmawiała Monika Branicka, „Art \& Business", [w:] Opowieść o rzeczach niepotrzebnych. Edyta Sobieraj. Wystawa malarstwa, katalog wystawy, Salon Antykwaryczny „Nautilus”, 3-17.06.2005, Kraków 2005, s. 3.

A. Brincken, Przedmiot i reszta, [w:] Edyta Sobieraj. Malarstwo / Malerkunst, katalog wystawy, Galleri Gamlet Ormelet, Tjøme, Norwegia, Kraków 2006, s. 4. 


\section{Jacek Waltoś podkreślał zaś, że malarstwo Sobieraj}

nie ukrywa, a wręcz podkreśla swoje monotonne cechy, jakby $\mathrm{z}$ nich robiło programowe przesłanie. Wprowadza nas w swoistą aurę, na swój sposób czaruje i jego celem zdaje się stałe potwierdzanie rozpoznawalnych cech tak, żebyśmy go nie opuszczali, żebyśmy mogli w nie wejść, oswojeni coraz bardziej i nienarażeni na zmianę nastroju. Świadoma tej sytuacji autorka powiada: „Zatrzymuje się czas, nie ten ludzki, rwący naprzód, ale ten czas osobny, poza-czas. Czas constans, w którego zatrzymaniu spełnia się pamięć, historia, los i przeznaczenie”.

Świadectwem tych doświadczeń są zarówno jej obrazy z lat 9o., symbolicznie zatytułowane Księga światła, Dotyk światła ${ }^{7}$, czy najnowszy cykl płócien, w których uwaga malarki skłania odbiorcę do kontemplacji otaczającej rzeczywistości (il. 2).

W martwych naturach Janusza Matuszewskiego mamy również do czynienia ze skupieniem uwagi na wybranym motywie, studiowanym brawurowo, z zastosowaniem obfitej materii malarskiej, w jednej, kontemplacyjnej tonacji nokturnu (il. 3). Artysta chętnie powołuje się na ignacjańskie lectio divina, pisząc:

Stosowany w tamtym czasie (2000-2005) język zawiera rozbudowaną warstwę malarską, skalę szarości czy wyciszonych błękitów, które ujawnić miały również aurę, rodzaj połączenia fizykalności i niewidzialnej strony rzeczy. Zdaję sobie sprawę, że od języka się nie ucieknie, ale aby uczciwie uprawiać malarstwo, trzeba chyba opuścić poziom tylko estetyczny, branżową ciasnotę i iść na spotkanie rzeczy. Hałasowi sztuki przeciwstawić ciszę, ukrytą ciszę rzeczywistości. Bo jak pisze Henri J.M. Nouwen: „Życie, któremu brakuje centrum ciszy, jest zagrożone destrukcją"”.

W innym zaś miejscu Matuszewski poszerza tę myśl:

Szukamy samorealizacji czy szukamy Boga? Po co więc malowanie? Istnieje sposób pracy, który nie jest sprzeczny z modlitwą. Przeciwnie, jest nią napełniony. Sposób

6 J. Waltoś, [komentarz], [w:] Home. Edyta Sobieraj, katalog wystawy, Kunstverket Hovedøya Galleri, Norwegia, lipiec 2011, Kraków 2011, s. 12.

7 Zob. Edyta Sobieraj, katalog wystawy, Państwowa Galeria Sztuki w Legnicy, wrzesień 1997, Legnica 1997; Edyta Sobieraj. Malarstwo, Galeria BwA „Jatki” w Nowym Targu, marzec 2001, Nowy Sącz 2001.

8 Cyt. za: A. Organisty, Martwa natura w Akademii Sztuk Pięknych w Krakowie dzisiaj, „Quart. Kwartalnik Instytutu Historii Sztuki Uniwersytetu Wrocławskiego" numer specjalny 2 (2013) 28, s. 131. 
pracy, który pokonuje napięcie pomiędzy modlitwą a pracą. Można być kontemplatykiem pośród działania. Stopniowo uczymy się bowiem widzenia spraw nie swoimi oczami, ale oczami Boga. Tak rozumiem realizowanie kontaktu z fenomenem świętości. Świętość to dla nas ideał nieosiągalny, ale tylko dlatego, że przed nim uciekamy. On w nas jest, prawda o nas samych jest w nas. Świętość nie jest niedościgłym ideałem, jest raczej niechcianym ideałem. Jesteśmy powołani do świętości. Kontakt w obrazach ze świętością ma miejsce nie tylko wtedy, kiedy malujemy klęczącego czy świecę, to jasne. Cała dobra sztuka jest sakralna. Pejzaż czy garnki też odsyłają do świętości. Oto nasz cel - przemiana całej naszej istoty w Bożym świetle ${ }^{9}$.

Poprzez subtelne zestawienia kolorystycznych półtonów Matuszewski wydobywa najważniejsze fragmenty z półmroku kompozycji. Świetlistość wybranych motywów w jego obrazach postrzegać można zarówno w kontekście stricte formalnym, świadczącym o wirtuozerii malarza, jak i semantycznym. Medytacyjny charakter oraz odniesienia do tradycyjnej symboliki światła można odnaleźć w malarstwie uczniów Matuszewskiego ${ }^{10}$. Nie odnoszą się oni bezpośrednio do jego postkapistowskiej maniery, ale do poglądów artystycznych czy wręcz moralnych. Kontemplacyjność, pokorne skupienie uwagi na otaczającej rzeczywistości charakteryzuje martwe natury Katarzyny Makieły-Organisty, asystentki Matuszewskiego. Jej monograficzne wystawy opatrzone były wymownymi tytułami Moje ołtarze i Refugium. Miejsce osobne ${ }^{11}$. Dla ostatniej ekspozycji mottem były słowa wyjęte z wizji św. Faustyny Kowalskiej: „Jestem Panem w istności swojej i nie znam nakazów ani potrzeb. Jeśli powołuję stworzenia do bytu - jest to przepaść miłosierdzia mego" ${ }^{12}$. Najnowsze obrazy Makieła-Organisty dedykuje mistrzom barokowym. Pomimo bezpośrednich nawiązań bądź cytatów kompozycyjnych są one przykładem twórczego formułowania nowych jakości z przywoływanych elementów. Poszczególne motywy w jej malarstwie postrzegać

9 Cyt. za: A. Organisty, „Na przebłaganie za grzechy nasze...”..., dz. cyt., s. 249.

${ }^{10}$ Por. Dariusz Milczarek. Wystawa malarstwa „Portret światta”, folder wystawy, Galeria Onamato, listopad 2011, Kraków b.r. [2011].

${ }^{11}$ Zob. Katarzyna Makieła. Moje ołtarze. Malarstwo, katalog wystawy, Galeria Artemis, lutymarzec 2012, red. J. Górka-Czarnecka, Kraków 2012; J. Żmudziński, [wprowadzenie], [w:] Refugium. Miejsce osobne. Katarzyna Makieła-Organisty. Malarstwo, rysunek, folder wystawy, oprac. A. Orłowska, Galeria Współczesnej Sztuk Sakralnej „Dom Praczki” w Kielcach, listopad 2013 luty 2014, Kielce 2013.

${ }^{12}$ Cyt. za: S. M. Faustyna Kowalska, Dzienniczek. Miłosierdzie Boże w duszy mojej, Warszawa 1996, s. 49. 
można w kontekście tradycyjnej symboliki religijnej i odniesień do arcydzieł Francisco de Zurbarána (il. 4).

„Pierwsza i najważniejsza korzyść, jaką przynosi oschła i ciemna noc kontemplacji, to poznanie siebie i swojej nędzy" - pisze św. Jan od Krzyża w Nocy ciem$n e j^{13}$. Zaprezentowane powyżej martwe natury Matuszewskiego, niczym obrazy malowane o zmierzchu, uzupełniać może seria jego płócien przedstawiających czaszki $^{14}$ (il. 5). Owe wanitatywne motywy niejako wyłaniają się z ciemności, przywodząc na myśl opisane przez św. Teresę od Jezusa w Księdze fundacji wrażenia $\mathrm{z}$ wizyty $\mathrm{w}$ jednym $\mathrm{z}$ pierwszych kościołów, reformowanych dzięki zaangażowaniu jej i św. Jana od Krzyża („Wszedłszy do kościółka, zdumiałam się, widząc wszędzie oznaki gorącości ducha, jaką Pan był ten nowy dom napełnił: wszędy na ścianach same tylko krzyże albo trupie głowy") ${ }^{15}$. W obrazach niemal wszystkich wspominanych tu krakowskich malarzy uwagę przykuwa predylekcja do tematyki ars moriendi. W bodegonach Grzegorza Bednarskiego, obejmujących kuchenne przedmioty zestawione z ludzkimi kośćmi, wanitatywne treści podkreśla ołowiowa tonacja blaszanych sztućców, rybich łusek wtopionych jak powiada Jacek Waltoś - „w perłowo szary koloryt medytacji” ${ }^{16}$. Natomiast malowane przez Katarzynę Makiełę-Organisty zwierzęce czerepy, oparte o barokowe wzory, nawiązują do moralizatorsko-dydaktycznej wymowy, skłaniając do refleksji nad życiem doczesnym i do rozwoju życia wewnętrznego. Wydają się one bliskie elementom „teologii mistycznej” opisanym przez św. Teresę od Jezusa - rozważaniom „nad niskością naszą i nad niewdzięcznością naszą względem Boga za tyle dobrodziejstw"17.

${ }_{13}$ Św. Jan od Krzyża, Dzieła, tłum. B. Smyrak ocD, red. P. Linka ocD, Kraków 2010, s. 531; por. N. Cummins ocD, Wprowadzenie do nauki św. Jana od Krzyża, tłum. T. Kieniewicz ocD, Kraków 1992, s. 73.

${ }^{14}$ Zob. Janusz Matuszewski, katalog wystawy, Galeria u Jezuitów, dz. cyt.; A. Organisty, Martwa natura..., dz. cyt., s. 129.

15 Św. Teresa od Jezusa, Dzieła, t. 2: Księga fundacji, tłum. H. P. Kossowski, Kraków 1987, s. 542-543. Symbole śmierci przypominają o przemijaniu, wskazując na rolę pamięci, jednej $\mathrm{z}$ trzech władz duszy. Pamięć rozbudza w niej pragnienie przejścia przez komnaty drugiego mieszkania, opisanego przez św. Teresę w Twierdzy wewnętrznej. Zob. św. Teresa od Jezusa, Dzieła, t. 2, dz. cyt., s. 244-245.

${ }^{16}$ A. Organisty, „Marzenia ściętej głowy”? Sakralizacja motywów barokowych w najnowszych pracach Grzegorza Bednarskiego, [w:] Barok i barokizacja..., dz. cyt., s. 389; por.: Grzegorz Bednarski, teksty: J. Waltoś, G. Bednarski, katalog wystawy, Galeria Zamkowa, Lublin, b.r. [1997]; Niezwyczajne. Z cyklu: Rektorzy i Forma. Wystawa Trzecia, katalog wystawy, Galeria Malarstwa AsP, oprac. A. Brincken, Kraków 2004, s. 18.

${ }_{17}$ Św. Teresa od Jezusa, Dzieła, t. 1: Księga życia, tłum. H. P. Kossowski, Kraków 1997, s. 186. 
Meditatio mortis obecne jest również w malarstwie Mirosława Sikorskiego. O jego związkach z twórczością El Greca referowałem w trakcie sesji poświęconej sztuce czasów mistrza $\mathrm{z}$ Toledo ${ }^{18}$. Przekonuje o tym także prezentowana od marca do września 2015 roku na Zamku w Niepołomicach wystawa Apostolado. W tym momencie pragnę zwrócić uwagę na dwa cykle Sikorskiego. W tryptyku zatytułowanym Enfleurages uwypuklona została metaforyka funeralna, poprzez intensyfikację skontrastowanej kolorystyki bukietów kwiatów z czaszkami ${ }^{19}$ (il. 6). Przywodzą one w pamięci typ bodegones, określany jako desengaños de la vida, we współczesnej historii sztuki nazywane „uświęconymi martwymi naturami” (naturaleza muerta sacralizada). Podobnie jak wyrafinowane barokowe alegorie przemijania, kompozycje krakowskiego twórcy odwołują się do emocji, zmysłów i intelektu odbiorcy, stawiając pytania o kondycję ludzkiej egzystencji. Drugim przykładem dzieł Sikorskiego o charakterze wanitatywnym, tym razem nawiązującym do ikonografii tańca śmierci, jest cykl Sekwencja zdarzeń (il. 7). Pierwszy obraz w tej serii składa się ze swego rodzaju predelli, przedstawiającej szkielety Don Kichota i Rosynanta zmierzających na spotkanie ze szkieletem kardynała Fernanda Niño de Guevara, pędzla Domenica Theotocopulosa ${ }^{20}$. Górna część tej kompozycji wyobraża zaś skłębiony tłum duchownych, zainspirowany zdjęciami z momentu Mszy pogrzebowej papieża Jana Pawła II. Poruszone wiatrem postacie w strojach biskupich i kardynalskich pojawiają się i w pozostałych obrazach cyklu, stanowiącego swego rodzaju próbę zmierzenia się z przedstawieniem śmierci osoby, którą zna cały świat.

O ile obrazy Sikorskiego nawiązują do twórczości El Greca i popularnych wyobrażeń imagines mortis, o tyle cykl płócien Grzegorza Bednarskiego zatytułowany Ni más ni menos oparty jest o eschatologiczne przesłanie „hieroglifów

${ }_{18}$ Zob. A. Organisty, El Greco według Mirosława Sikorskiego, [w:] Sztuka doby El Greca. Materiały z międzynarodowej konferencji zorganizowanej przez Instytut Historii Sztuki i Kultury Uniwersytetu Papieskiego Jana Pawła II w Krakowie oraz Zamek Królewski w Warszawie, [w druku].

19 Zob. Enfleurage. L'essence absolue. Mirosław Sikorski. Obrazy, folder wystawy, Politechnika Krakowska, Galeria Gil, Kraków 2004; M. Sikorski, Enfleurages. Uwagi o związkach obrazu poetyckiego i obrazu malarskiego (fragmenty), "Zeszyty Naukowo-Artystyczne. Wydział Malarstwa Akademii Sztuk Pięknych w Krakowie" 6 (2005), s. 37-56; Odnajdywanie piękna. Finding Beauty. Rinvenire il Bello. Wystawa artystów-pedagogów Akademii Sztuk Pięknych w Krakowie, Pałac Sztuki Towarzystwa Przyjaciół Sztuk Pięknych w Krakowie, red. K. Nowak, Kraków 2008, s. 58-59, 168-169; A. Organisty, Martwa natura..., dz. cyt., s. 134-137.

${ }^{20}$ Zob. Don Kichot. Współczesna próba..., dz. cyt., nlb. [s. 28]; Kardynał de Guevara idzie do nieba. Sikorski. Obrazy, Miejska Galeria Sztuki w Częstochowie, 28.05. - 28.o6.2009, Miejska Galeria Sztuki im. Władysława hr. Zamoyskiego w Zakopanem, red. K. Nowak, Kraków 2009, s. $62-63$. 
śmierci" Juana de Valdés Leala. Bednarski przejął tytuł serii z jednego z dwóch obrazów z roku 1672 (Finis Gloriae Mundi), znajdującego się w Szpitalu Miłosierdzia w Sewilli.

Moje przeżycia związane z obrazami Leala - podkreśla krakowski artysta - nie są natury bezpośredniej. To, co mnie z nimi wiąże, to przede wszystkim tytuł: Ni más ni menos, będący cytatem wyjętym z jednego z obrazów (tam, gdzie ręka wyłaniająca się spoza chmur waży to, co dobre i to, co złe). Tytuł, który wydał mi się istotny, najbardziej właściwy moim usiłowaniom. To, co mnie z tymi obrazami łączy, to między innymi $[\ldots]$ wspólnota myślenia ${ }^{21}$.

W obrazach z lat 8o., z towarzyszącym im podtytułem Czarna Seria, Bednarski zwraca uwagę na problematykę Odkupienia, przywołując poszczególne motywy z sewilskiego płótna Valdésa Leala Finis Gloriae Mundi (1672). Brutalną, ekspresyjną manierę Bednarski rozwijał z początkiem XxI wieku w rozbudowywanych do kilkudziesięciu prac zespołach: Hedonista maluje Ukrzyżowanie (1998-2003, przywodzący na myśl stacje Drogi Krzyżowej), Popielec (2001-2004) czy Personifikacje (od 1998). „Obrazy te charakteryzuje - jak pisze Krzysztof Lipka - swoisty dynamizm i patos, który dla artysty jest rodzajem wiary w nieuchronność cierpienia" ${ }^{22}$. Tę "gorącą potrzebę mówienia niemalże wprost o sprawach trudnych, jak chociażby wina i kara”, podkreśla też Kitowska-Łysiak, dodając, że „niezwykle wyrazisty jest pod tym względem wspomniany już «pokutniczy» Popielec - seria płócien niemalże modułowych, zbliżonych do siebie rozmiarami, utrzymanych w popiołowej gamie barwnej”23. Personifikacje pędzla Bednarskiego to wielofigurowe sceny nawiązujące do tekstów Starego Testamentu, żywotów świętych i pism mistyków. W kompozycjach tych, dodaje Kitowska-Łysiak, „główny akcent położony jest często nie na postać, której dotyczy jedna czy druga historia

${ }^{21}$ Cyt. za: Nie czuję się zdrajca... Z Grzegorzem Bednarskim rozmawia Krystyna Czerni, „Kresy” 4 (1994) 20, s. 203; por. A. Organisty, „Marzenia ściętej głowy”..., dz. cyt., s. 388-389.

${ }^{22}$ K. Lipka, Grzegorza Bednarskiego „Figur racje”, [w:] Figury i figuracje. Materiały LIV ogólnopolskiej sesji naukowej Stowarzyszenia Historyków Sztuki, Lublin, 20-22 października 2005, red. M. Kitowska-Łysiak i in., Warszawa 2006, s. 332, przyp. 3. Por. na ten temat: D.K. Łuszczek ospPE, Inspiracje religijne w polskim malarstwie i grafice 1981-1991, red. K. Kublaska-Sulkiewicz, Gdańsk 1998, s. 224-225; R. Rogozińska, W stronę Golgoty. Inspiracje pasyjne w sztuce polskiej w latach 1970-1999, red. H. Hilbert, Poznań 2002, s. 234-237.

${ }_{23}$ M. Kitowska-Łysiak, Powolne czytanie malowidet, [w:] Grzegorz Bednarski, katalog wystawy, Galeria u Jezuitów, Poznań 2004, nlb. [s. 8]. Por. A. Organisty, „Na przebłaganie za grzechy nasze...”..., dz. cyt., s. 240-246. 
o chwalebnym męczeństwie, lecz znaczący symbolicznie przedmiot”" ${ }^{24}$. W Modlitwie św. Katarzyny z Sieny o zbawienie dusz wszystkich przy wsparciu św. Teresy przeskalowane, natarczywie realistyczne detale podkreślają znaczenie przedstawionej wizji piekła (il. 8), jaką miała z początkiem roku 1560 św. Teresa z Ávila:

Byłam na modlitwie, gdy nagle, nie wiadomo jak, wydało mi się, że Pan chciał mi pokazać miejsce, jakie mi tam szatani przygotowali i na jakie sama zasłużyłam przez swoje grzechy. [...] Na dole była jakby woda błotnista, bardzo brudna i cuchnąca, ponadto pełna okropnych stworów. Na końcu znajdowało się zagłębienie w murze, podobne do szafy ściennej, i tam ujrzałam się nagle wtłoczona. [...] W duszy swej poczułam ogień, którego nie umiałabym opisać. Ból ciała był nie do wytrzymania. [...] Powiedzieć, że było to nieustanne wyrywanie duszy - to mało; znaczyłoby to tylko, że ktoś inny duszę nam wydziera, lecz tam dusza sama rwała się na kawałki. [...] Nie wiedziałam, kto mi te cierpienia zadawał, ale czułam, że płonę i jestem jakby rozszarpywana na części ${ }^{25}$.

Obraz ten, jak i omówiona przeze mnie przed laty Rozmowa św. Jana od Krzyża ze św. Teresa z Ávila, świadczą o fascynacji Bednarskiego fabułą bądź chęcią zilustrowania poszczególnych wydarzeń związanych z przeżyciami doktorów Kościoła ${ }^{26}$. Skłonność malarza do tematów trudnych, przedstawień dramatycznych wyrasta, jak sugeruje Renata Rogozińska, „z przeświadczenia, że bojaźń Boża, nota bene jeden $\mathrm{z}$ siedmiu darów Ducha Świętego, to trwały element postawy człowieka wobec Stwórcy i zarazem pozytywny i niezbędny składnik naszej duchowości” ${ }^{\prime 27}$. Podobną potrzebę prowadzenia opowieści obserwować można w malarstwie ucznia Bednarskiego, Wojciecha Szybista (il. 9). Wątki pasyjne czy eschatologiczne obrazuje on w znacznie bardziej wyciszonej aurze, skłaniającej do kontemplacji wyobrażonych przezeń motywów, kształtujących narrację.

${ }^{24}$ M. Kitowska-Łysiak, Powolne czytanie malowideł, dz. cyt., nlb. [s. 11].

25 Św. Teresa od Jezusa, Dzieła, t. 1, dz. cyt., s. 419, a także s. 420: „Nie widziałam ręki, która mi te katusze zadawała, ale czułam, że się palę, że jestem jakby targana i sieczona na sztuki. Tak jest, powtarzam: ten ogień wewnętrzny i ta rozpacz duszy, ta jest męka nad wszelkie męki najsroższa”; por.: M. Lépée, Święta Teresa z Ávila - mistyczka, tłum. E. Szwarcenberg-Czerny, Warszawa 1995, s. 125-126; A. Organisty, „Marzenia ściętej głowy”..., dz. cyt., s. 392-393.

${ }^{26}$ Zob. A. Organisty, „Marzenia ściętej głowy”..., dz. cyt., s. 396-397.

${ }_{27}$ Cyt. za: R. Rogozińska, „Apokalipsa” według Grzegorza Bednarskiego. Eskalacja zła czy orędzie nadziei?, „Sacrum et Decorum. Materiały i Studia z Historii Sztuki Sakralnej / Materials and Studies on the History of Sacred Art" 3 (2010), s. 112. 
Zabieg kondensacji i jukstapozycji - zestawienia różnych płaszczyzn obok siebie: realistycznej, imaginowanej czy wspomnieniowej - obserwujemy głównie w wielofigurowych płótnach Janusza Matuszewskiego. Malarz identyfikuje się nieomal z historycznym kostiumem barokowego malarstwa cechowego - prezentowany przezeń ostatnio cykl autoportretów, określanych w słowach samego autora jako dewocyjne, budowany jest za pomocą przestrzeni o szkatułkowo otwierających się widokach wnętrz ${ }^{28}$. Poprzez rozświetlenia poszczególnych partii kolorów zespala realistyczne i wizyjne elementy kompozycji w jedną całość. W „dawnym stylu” dekorował on ponadto oprawy kilkunastu publikacji, m.in. najnowsze wydania Biblii, traktaty teologiczne czy pisma mistyków hiszpańskich (św. Jana od Krzyża). Dekoracje książek Matuszewskiego nie odnoszą się bezpośrednio do tekstów, ale wydają się symbolicznym obrazowaniem ich czytania. Pojawiającą się w niemal każdej oprawie malarskiej modlącą się postać, będącą najczęściej autoportretem artysty, interpretować można jako wyobrażenie aktu medytacji nad słowami przewodników duchowych. Takie rozwiązanie kompozycyjne przywodzi jednocześnie na myśl wyjątkowe dzieło Francisco de Zurbarána, wyobrażające malarza adorującego Chrystusa Ukrzyżowanego (ok. 1655-166o, Museo del Prado) ${ }^{29}$. Znamienne, że na jednym $z$ autoportretów Matuszewski przedstawił siebie w stroju zakonnym pod wyobrażeniem Chrystusa przy kolumnie (il. 10). Przed obrazem umęczonego Zbawiciela, dodajmy, doznała przemiany św. Teresa $\mathrm{z}$ Ávila. Z rozdziału dziewiątego jej autobiografii dowiadujemy się, że na charakter i osobowość jednej z najważniejszych postaci $\mathrm{w}$ historii Kościoła oddziałało artystyczne imago o dolorystycznej wymowie ${ }^{30}$.

Bogu dziękuję - pisze Matuszewski - że jakoś poprowadził mnie drogą, na której mogłem spotkać perły literatury duchowej, czy to karmelitańskiej czy też ignacjańskiej, które pozwalają zobaczyć czy przeczuć twardą, niezmienną rzeczywistość, niezależną od naszego subiektywizmu, od naszego „wydaje mi się... Pozwala mi to też na ocenę i tego, co dzieje się dziś w mojej branży, tzw. sztuce ${ }^{31}$.

${ }_{28}$ Por. np. J. Gongała, Janusz Matuszewski. Natchniony sztuką barokową. Galeria Wspólna MCK w Bydgoszczy, 4 IX - 5 X 2014, „Wiadomości Akademii Sztuk Pięknych w Krakowie” 68 (2015) styczeń, s. 92-93.

29 Zob. A. Organisty, Pokorna ozdoba na karbonach duchowych uczyniona, [w:] Janusz Matuszewski. Pokorna ozdoba na karbonach duchowych uczyniona, folder wystawy, Galeria Jednej Książki Biblioteki Głównej Akademii Sztuk Pięknych im. Jana Matejki w Krakowie, 19.03. 30.04.2010, Kraków 2010; A. Organisty, „Na przebłaganie za grzechy nasze...”..., dz. cyt., s. 249.

3o Zob. św. Teresa od Jezusa, Dzieła, t. 1, dz. cyt., s. 179-18o.

${ }^{31}$ List prywatny do autora artykułu (6.02.2014). 


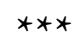

Podsumowując, warto zadać pytanie o przyczyny omówionego powyżej zjawiska artystycznego, którego charakterystyczną cechą jest nie tylko prowadzony przez artystów dialog ze sztuką barokową. Wyraźnie widoczna jest tu zarówno potrzeba poruszenia tematów egzystencjalnych, obrazujących tematykę przemijania, jak i religijnych, odnoszących się do pism mistyków hiszpańskich. Wpływ na wyobraźnię malarzy wykształconych w większości w ostatniej ćwierci minionego stulecia mogły mieć zainteresowania ich nauczycieli. W latach $80 . \mathrm{xx}$ wieku w Akademii Sztuk Pięknych w Krakowie pojawił się silny nurt figuracji, mającej swoje źródła w sztuce przedstawicieli grupy Wprost, nawiązujących do nowożytnej ikonografii. Powstające wówczas obrazy Grzegorza Bednarskiego, Tadeusza Boruty czy Aldony Mickiewicz łączy potrzeba prowadzenia narracji o religijnej wymowie. Wspólne źródła inspiracji nadal można dostrzec w obrazach tych artystów, a także płótnach Sikorskiego czy Makieły-Organisty. Pewne znacznie mogły mieć i lektury z zakresu historii sztuki, jak chociażby znakomite, podręcznikowe omówienie sztuki hiszpańskiej pióra Marii Rzepińskiej. Z drugiej strony zaprezentowane powyżej zjawisko hiszpańskiego barokizmu na gruncie krakowskiej Akademii wydaje się potrzebą realizacji malarstwa, niezależnego od mody narzucanej przez rynek sztuki. Omówione malarstwo wyraźnie kładzie nacisk nie tylko na wysmakowaną formę artystyczną, ale i na wartości duchowe, płynące $\mathrm{z}$ barokowego malarstwa hiszpańskiego, stąd wynika potrzeba nawiązania do niego poprzez elementy formalne bądź tematyczne. Różni się to znacznie od obecnych w tym samym czasie i nagłośnionych przez media nurtów w sztuce - od sztuki krytycznej począwszy, poprzez tzw. „efekt Tuymansa”, aż po realizacje z pogranicza popularnego niedawno neosurrealizmu. Co więcej, dla omówionych powyżej twórców charakterystyczne jest również odejście od obrazowania abstrakcyjnego na rzecz malarstwa realistycznego czy figuratywnego. Wystarczy przyjrzeć się okładkom książek na temat teologii mistycznej św. Jana od Krzyża - jedna z najciekawszych, opublikowanych ostatnio, pióra Alicji Walerich, opatrzona została abstrakcyjną kompozycją Gerharda Richtera z roku 2013. W ogólnym przeświadczeniu nadal panuje przekonanie, że „o duchowości w sztuce", jak pisał Kandyński, najlepiej opowiadają obrazy abstrakcyjne czy suprematystyczne. Obrazy krakowskich twórców przyznają się do zupełnie innej tradycji. Tematyka przemijania czy religijne treści, podobnie jak dla twórców potrydenckich obrazowanie scen religijnych, mają być nieomal dosłowne, aby jak pisał św. Ignacy Loyola w Ćwiczeniach duchownych - „zobaczyć wzrokiem wyobraźni”, „wyobrazić sobie miejsca” lub „rekonstruować wydarzenia”. 
Mówiąc jednak o mistycyzmie krakowskiego malarstwa współczesnego, należy wystrzegać się, jak przestrzegał Thomas Merton, przywłaszczonego przez krytyków literatury i historyków od czasów romantyzmu terminu, stosowanego wobec każdego, kto pragnie „uwolnić emocjonalną i afektywną stronę życia ludzkiego od hamulców konwencjonalnych lub oddziałujących norm myślenia" ${ }^{32}$. Mistyka, zgodnie z definicją, obejmuje bowiem nie wywołane przez człowieka doświadczenie obecności Boga wewnątrz osoby ludzkiej. Omówione obrazy mogą być więc punktem wyjściowym dla medytacji nad wyobrażeniowymi i materialnymi przedstawieniami, prowadzącymi - zgodnie z tradycją wywodzącą się od św. Pawła (Rz 1, 20) - do „wypatrywania” Boskiej obecności w zmysłowej rzeczywistości obrazu.

\section{Bibliografia}

\section{Źródła}

Kowalska M. F., Dzienniczek. Miłosierdzie Boże w duszy mojej, Warszawa 1996.

Św. Jan od Krzyża, Dzieła, tłum. B. Smyrak ocD, red. P. Linka ocD, Kraków 2010.

Św. Teresa od Jezusa, Dzieła, t. 2: Księga fundacji, tłum. H. P. Kossowski, Kraków 1987.

Św. Teresa od Jezusa, Dzieła, t. 1: Księga życia, tłum. H. P. Kossowski, Kraków 1997.

\section{Opracowania}

Bednarski Grzegorz, teksty J. Waltoś, G. Bednarski, katalog wystawy, Galeria Zamkowa, Lublin, b.r., b.m.w. [1997].

Bednarski G., Prawo rzeczowości. Poetyckie malarstwo Zbigniewa Sprychy, „Wiadomości Akademii Sztuk Pięknych w Krakowie" 49 (2010) kwiecień, s. 50-51.

Brincken A., [wprowadzenie], [w:] Zbigniew Sprycha, katalog wystawy, Dom Kultury Podgórze - Centrum Sztuki Współczesnej „Solvay”, Kraków b.r. [2001], nlb. [s. 3].

Brincken A., Przedmiot i reszta, [w:] Edyta Sobieraj. Malarstwo / Malerkunst, katalog wystawy, Galleri Gamlet Ormelet, Tjøme, Norwegia, Kraków 2006, s. 4.

Cummins N., Wprowadzenie do nauki św. Jana od Krzyża, tłum. T. Kieniewicz ocD, Kraków 1992.

Czerni K., Popiół i diament, [w:] Janusz Matuszewski, katalog wystawy, Galeria u Jezuitów, Poznań 2004, nlb. [s. 7-11].

${ }^{32}$ T. Merton, Wspinaczka ku prawdzie, rozdz. 6: Fałszywa mistyka (mistycyzm), [w:] T. Merton, Szukanie Boga, tłum. P. Parlej, Kraków 1988, s. 62. 
Czerni K., Zielona Infantka albo Mistrz i Małgorzata, [w:] Zbigniew Sprycha, katalog wystawy, Galeria u Jezuitów, Poznań 2004, nlb. [s. 7-11].

Czerni K., „My wszyscy, którzy rośliśmy w miastach Baroku...”- czyli o fascynacji barokiem współczesnych malarzy krakowskich, [w:] Barok i barokizacja. Materiały sesji Oddziału Krakowskiego Stowarzyszenia Historyków Sztuki Kraków 3-4 XII 2004, red. K. Brzezina, J. Wolańska, Kraków 2007, s. 371-383 (Ars Vetus et Nova, red. W. Bałus, t. 28).

Don Kichot. Współczesna próba interpretacji, katalog wystawy, Galeria Dominika Rostworowskiego, Kraków, 5.-17.11.2004, Kraków 2004, nlb. [s. 42-43].

Enfleurage. L'essence absolue. Mirosław Sikorski. Obrazy, folder wystawy, Politechnika Krakowska, Galeria Gil, Kraków 2004.

Gongała J., Janusz Matuszewski. Natchniony sztuką barokową. Galeria Wspólna MCK w Bydgoszczy, 4 IX - 5 X 2014, „Wiadomości Akademii Sztuk Pięknych w Krakowie” 68 (2015) styczeń, s. 92-93.

Kardynat de Guevara idzie do nieba. Sikorski. Obrazy, Miejska Galeria Sztuki w Częstochowie, 28.05.-28.06.2009, Miejska Galeria Sztuki im. Władysława hr. Zamoyskiego w Zakopanem, red. K. Nowak, Kraków 2009, s. 62-63.

Kitowska-Łysiak M., Powolne czytanie malowideł, [w:] Grzegorz Bednarski, katalog wystawy, Galeria u Jezuitów, Poznań 2004, nlb. [s. 8-11].

Kitowska-Łysiak M., Barokista, [w:] Janusz Matuszewski. Malarstwo, folder wystawy, Galeria Współczesnej Sztuki Sakralnej „Dom Praczki” w Kielcach, maj-lipiec 2012, oprac. A. Orłowska, Kielce 2012.

Lépée M., Święta Teresa z Ávila - mistyczka, tłum. E. Szwarcenberg-Czerny, Warszawa 1995.

Lipka K., Grzegorza Bednarskiego „Figur racje”, [w:] Figury i figuracje. Materiały LIV ogólnopolskiej sesji naukowej Stowarzyszenia Historyków Sztuki, Lublin, 20-22 października 2005, red. M. Kitowska-Łysiak i in., Warszawa 2006, s. 331-346.

Łuszczek osppe D. K., Inspiracje religijne w polskim malarstwie i grafice 1981-1991, red. K. Kublaska-Sulkiewicz, Gdańsk 1998.

Makieła Katarzyna. Moje ołtarze. Malarstwo, katalog wystawy, Galeria Artemis, luty-marzec 2012, red. J. Górka-Czarnecka, Kraków 2012.

Merton T., Wspinaczka ku prawdzie, rozdz. 6: Fałszywa mistyka (mistycyzm), [w:] T. Merton, Szukanie Boga, tłum. P. Parlej, Kraków 1988, s. 61-69.

Milczarek Dariusz. Wystawa malarstwa „Portret światła”, folder wystawy, Galeria Onamato, listopad 2011, Kraków, b.r., b.m.w. [2011].

Nie czuję się zdrajcą... Z Grzegorzem Bednarskim rozmawia Krystyna Czerni, „Kresy” 4 (1994) 20, s. 203.

Niezwyczajne. Z cyklu: Rektorzy i Forma. Wystawa Trzecia, katalog wystawy, Galeria Malarstwa Asp, oprac. A. Brincken, Kraków 2004. 
Nowakowski A. Z., [wstęp], [w:] Sprycha. Malarstwo, katalog wystawy, Biuro Wystaw Artystycznych w Krakowie, czerwiec 1990, Kraków 1990, nlb. [s. 3].

Odnajdywanie piękna. Finding Beauty. Rinvenire il Bello. Wystawa artystów-pedagogów Akademii Sztuk Pięknych w Krakowie, Pałac Sztuki Towarzystwa Przyjaciół Sztuk Pięknych w Krakowie, red. K. Nowak, Kraków 2008, s. 58-59, 168-169.

Opowieść o rzeczach niepotrzebnych. Z Edytą Sobieraj rozmawiała Monika Branicka, „Art \& Business", [w:] Opowieść o rzeczach niepotrzebnych. Edyta Sobieraj. Wystawa malarstwa, katalog wystawy, Salon Antykwaryczny „Nautilus”, 3-17.06.2005, Kraków 2005, s. 3. Organisty A., „Marzenia ściętej głowy”? Sakralizacja motywów barokowych w najnowszych pracach Grzegorza Bednarskiego, [w:] Barok i barokizacja. Materiały sesji Oddziału Krakowskiego Stowarzyszenia Historyków Sztuki Kraków 3-4 XII 2004, red. K. Brzezina, J. Wolańska, Kraków 2007, s. 385-401 (Ars Vetus et Nova, red. W. Bałus, t. 28).

Organisty A., Pokorna ozdoba na karbonach duchowych uczyniona, [w:] Janusz Matuszewski. Pokorna ozdoba na karbonach duchowych uczyniona, folder wystawy, Galeria Jednej Książki Biblioteki Głównej Akademii Sztuk Pięknych im. Jana Matejki w Krakowie, 19.03.-30.04.2010, Kraków 2010.

Organisty A., Prace artystów z Wydziału Malarstwa Akademii Sztuk Pięknych w Krakowie, [w:] Akademia Sztuk Pięknych im. Jana Matejki w Krakowie. Wydział Malarstwa 2010 / Jan Matejko Academy of Fine Arts in Krakow. The Faculty of Painting 2010, red. Z. Bajek i in., Kraków b.r. [2011], s. 12-69.

Organisty A., Martwa natura w Akademii Sztuk Pięknych w Krakowie dzisiaj, „Quart. Kwartalnik Instytutu Historii Sztuki Uniwersytetu Wrocławskiego” numer specjalny 2 (2013) 28, s. 127-141.

Organisty A., „Na przebłaganie za grzechy nasze...” O malarstwie religijnym Grzegorza Bednarskiego i Janusza Matuszewskiego, „Ethos. Kwartalnik Instytutu Jana Pawła II KUL Lublin i Fundacji Jana Pawła II - Rzym” (2014) 105, s. 239-253.

Organisty A., O infantkach w twórczości malarskiej Zbigniewa Sprychy, [w:] [publikacja na temat polskich przedstawień Infantki Małgorzaty], red. J. Malinowski (Studia o Sztuce Nowoczesnej) [w druku].

Organisty A., El Greco wedtug Mirosława Sikorskiego, [w:] Sztuka doby El Greca. Materiały $z$ międzynarodowej konferencji zorganizowanej przez Instytut Historii Sztuki i Kultury Uniwersytetu Papieskiego Jana Pawła II w Krakowie oraz Zamek Królewski $w$ Warszawie, [w druku].

Rogozińska R., W stronę Golgoty. Inspiracje pasyjne w sztuce polskiej w latach 1970-1999, red. H. Hilbert, Poznań 2002.

Rogozińska R., „Apokalipsa” według Grzegorza Bednarskiego. Eskalacja zła czy orędzie nadziei?, „Sacrum et Decorum. Materiały i Studia z Historii Sztuki Sakralnej / Materials and Studies on the History of Sacred Art" 3 (2010), s. 95-114. 
Sikorski M., Enfleurages. Uwagi o związkach obrazu poetyckiego i obrazu malarskiego (fragmenty), „Zeszyty Naukowo-Artystyczne. Wydział Malarstwa Akademii Sztuk

Pięknych w Krakowie" 6 (2005), s. 37-56.

Sobieraj Edyta, katalog wystawy, Państwowa Galeria Sztuki w Legnicy, wrzesień 1997, Legnica 1997.

Sobieraj Edyta. Malarstwo, Galeria BwA „Jatki” w Nowym Targu, marzec 2001, Nowy Sącz 2001.

Sprycha, Galeria Akademii, ul. Bracka 4, Kraków, styczeń-luty 1987, b.r., b.m.w.

Sprycha. Malarstwo, katalog wystawy, Biuro Wystaw Artystycznych w Krakowie, czerwiec 1990, Kraków 1990, nlb. [s. 5].

Sprycha Zbigniew. Malarstwo, katalog wystawy, Galeria Krypta u Pijarów, grudzień 2006, Kraków 2006, nlb. [s. 5].

Tabisz S., Nieobecność infantki. Nowe obrazy Zbigniewa Sprychy, [w:] Zbigniew Sprycha. Wystawa malarstwa, katalog wystawy, Salon Antykwaryczny „Nautilus”, Kraków, 10-30.06.2006, Kraków 2006, s. 3.

Waltoś J., [komentarz], [w:] Home. Edyta Sobieraj, katalog wystawy, Kunstverket Hovedøya Galleri, Norwegia, lipiec 2011, Kraków 2011, s. 12.

Żmudziński J., [wprowadzenie], [w:] Refugium. Miejsce osobne. Katarzyna Makieła-Organisty. Malarstwo, rysunek, folder wystawy, oprac. A. Orłowska, Galeria Współczesnej Sztuk Sakralnej „Dom Praczki” w Kielcach, listopad 2013-luty 2014, Kielce 2013.

\section{Abstrakt}

W ciągu ostatnich dwóch dekad w twórczości pedagogów Wydziału Malarstwa Akademii Sztuk Pięknych w Krakowie - Grzegorza Bednarskiego, Katarzyny Makieły-Organisty, Janusza Matuszewskiego, Mirosława Sikorskiego, Edyty Sobieraj, Zbigniewa Sprychy czy Wojciecha Szybista - widoczne są inspiracje hiszpańskim malarstwem Złotego Wieku. Obrazy krakowskich malarzy wyróżniają się na tle współczesnej sztuki zarówno na gruncie polskim, jak i światowym. Ich płótna omawiać należy w kontekście nowożytnego meditatio mortis oraz tenebrystycznego „barokizmu”, do czego chętnie przyznają się sami artyści. Punktem wyjścia są (niejednokrotnie tytułowane jako homagium) wizje mistyczne, konterfekty pędzla El Greca, bodegony Francisco de Zurbarána czy eschatologiczne „hieroglify śmierci” Juana de Valdés Léala. Odwołaniom do dzieł mistrzów Półwyspu Iberyjskiego towarzyszą odniesienia do pism karmelitańskich czy jezuickich 
mistyków. Analiza nie tylko od strony formalnej, ale także ideowej pozwala zadać pytanie o możliwość obrazowania we współczesnym malarstwie o charakterze religijnym „teologii mistycznej”, opisanej przez św. Teresę od Jezusa, św. Jana od Krzyża czy św. Ignacego Loyoli.

\title{
Słowa kluczowe
}

malarstwo współczesne, Akademia Sztuk Pięknych w Krakowie, mistyka karmelitańska

\begin{abstract}
The Spanish mysticism in paintings by artists from the Fine Arts Academy in Krakow at the turn of the $21^{\text {st }}$ century
\end{abstract}

During the last two decades the works of teachers from the Painting Department of the Academy of Fine Arts in Krakow: Grzegorz Bednarski, Katarzyna Makieła-Organisty, Janusz Matuszewski, Mirosław Sikorski, Edyta Sobieraj, Zbigniew Sprycha or Wojciech Szybist reveal traces of inspiration by the Spanish Golden Age. In this respect, paintings by Krakow artists stand out against other works of contemporary art both in Poland and globally. Their art should be discussed in the context of early modern meditatio mortis and tenebristic „baroqueism”, to which the artists themselves readily admit. The point of departure (frequently referred to as homage) are mystic visions, portraits by El Greco, Francisco de Zurbarán’s bodegóns or eschatological „death hieroglyphics” by Juan de Valdés Léal. References to works by the Iberian masters are accompanied by links to Carmelite writings or Jesuit mystics. Formal and ideological analysis also allows us to ask a question of the possibility of presenting the "mystic theology” described by St. Theresa of the Infant Jesus, St. John of the Cross or St. Ignatius of Loyola in contemporary religious paintings.

\section{Keywords}

contemporary painting, Academy of Fine Arts in Krakow, Carmelite mysticism 


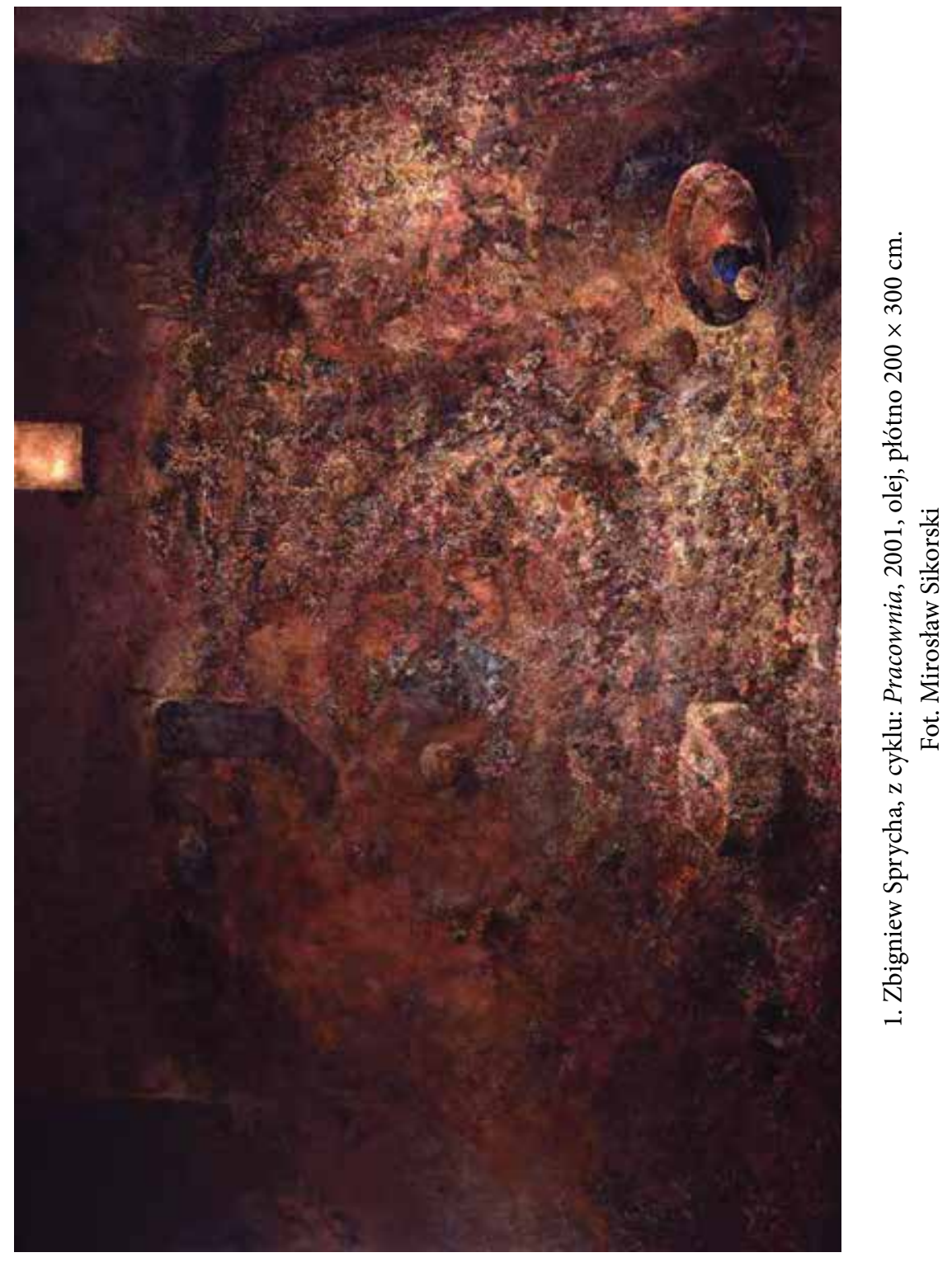




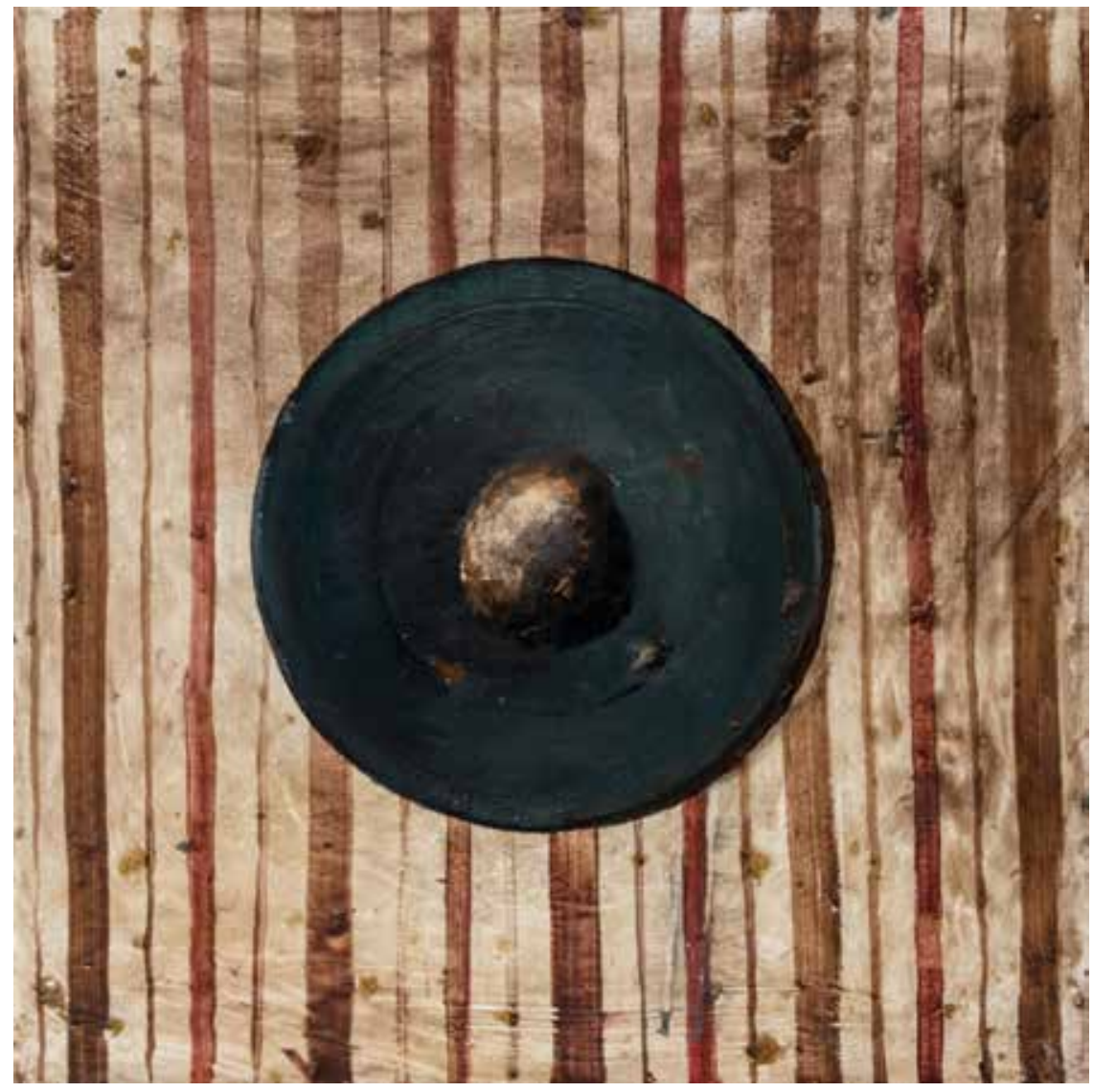

2. Edyta Sobieraj, Przedmiot, 2015, olej, płótno $50 \times 50 \mathrm{~cm}$. Fot. Mirosław Sikorski 


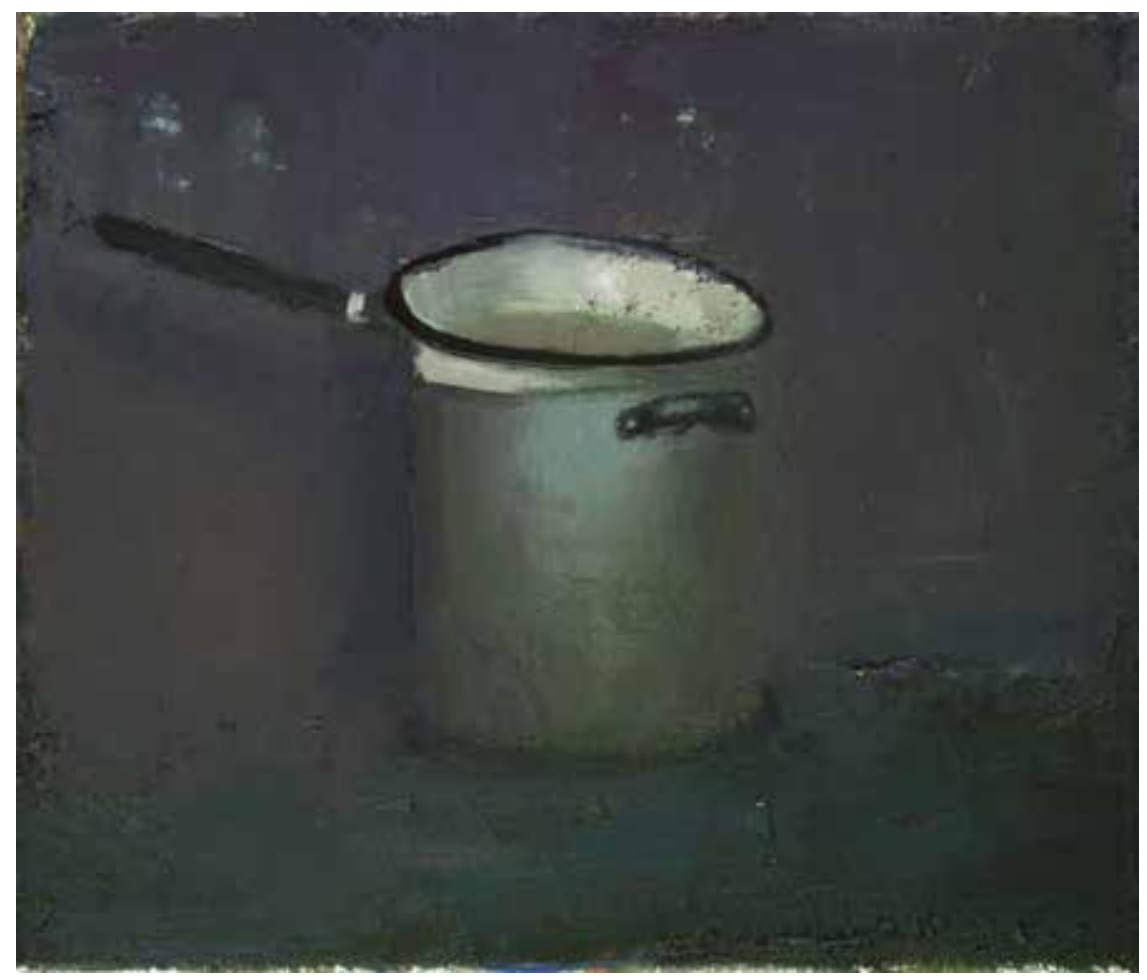

3. Janusz Matuszewski, Garnki, 2004, olej, płótno $30 \times 24 \mathrm{~cm}$.

Fot. ze zbiorów Janusza Matuszewskiego 


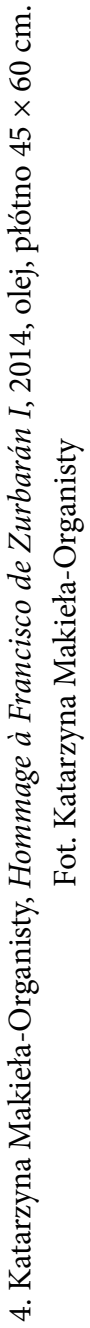




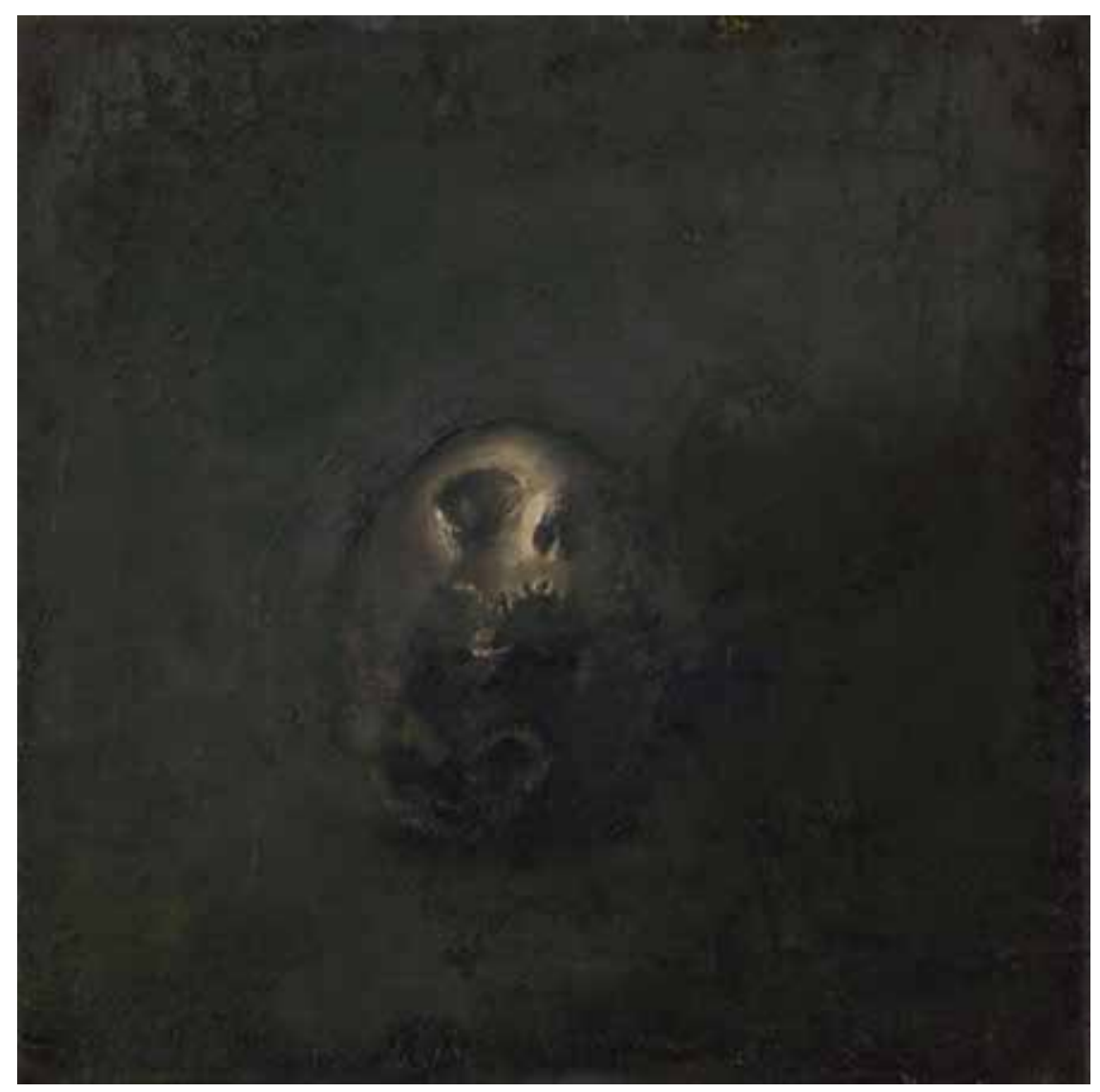

5. Janusz Matuszewski, Czaszka, 2004, olej, płótno $30 \times 24 \mathrm{~cm}$. Fot. ze zbiorów Janusza Matuszewskiego 


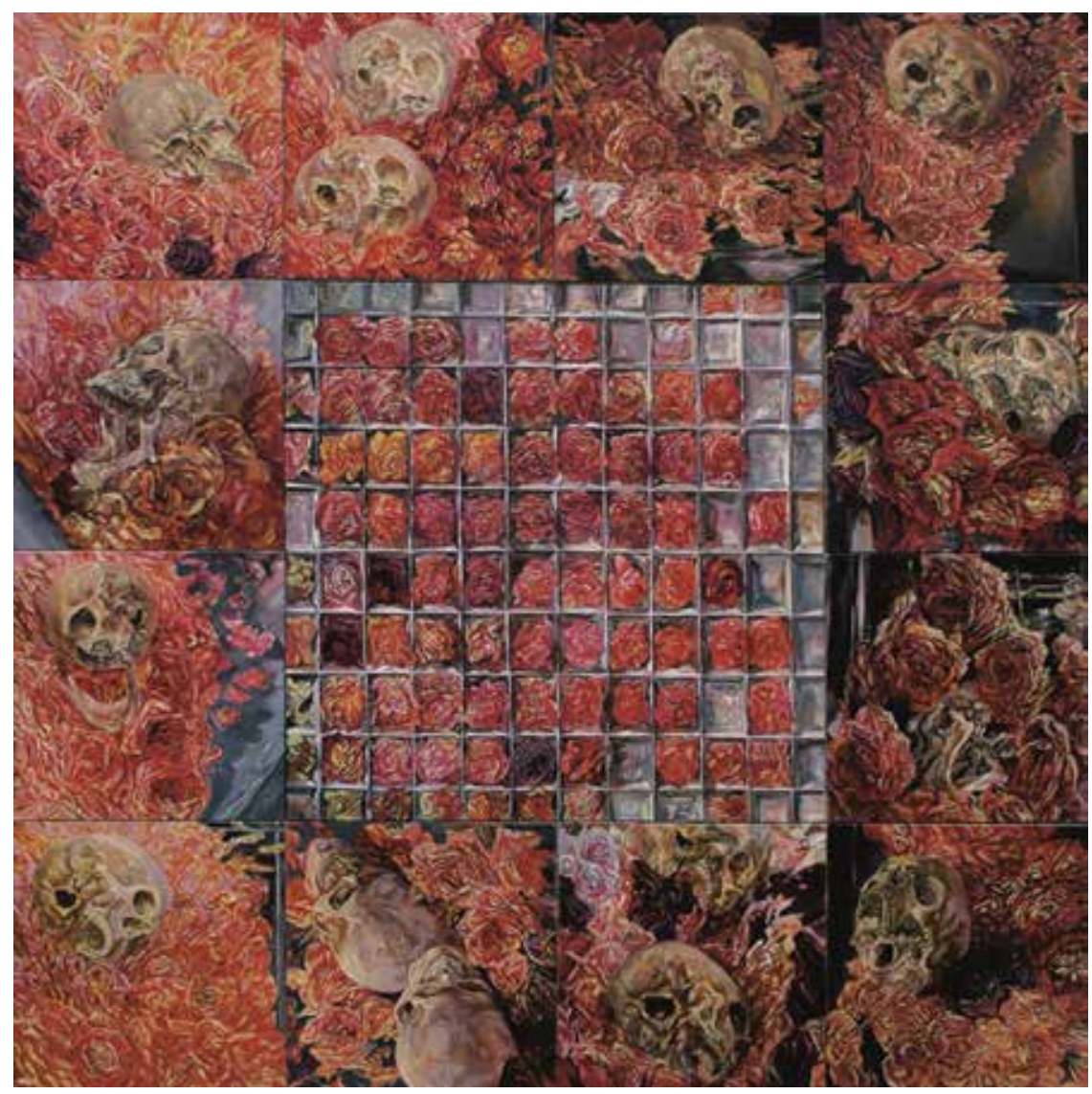

6. Mirosław Sikorski, Enfleurages, część tryptyku, 2003-2004, tempera, olej, płótno $200 \times 200 \mathrm{~cm}$.

Fot. Mirosław Sikorski 


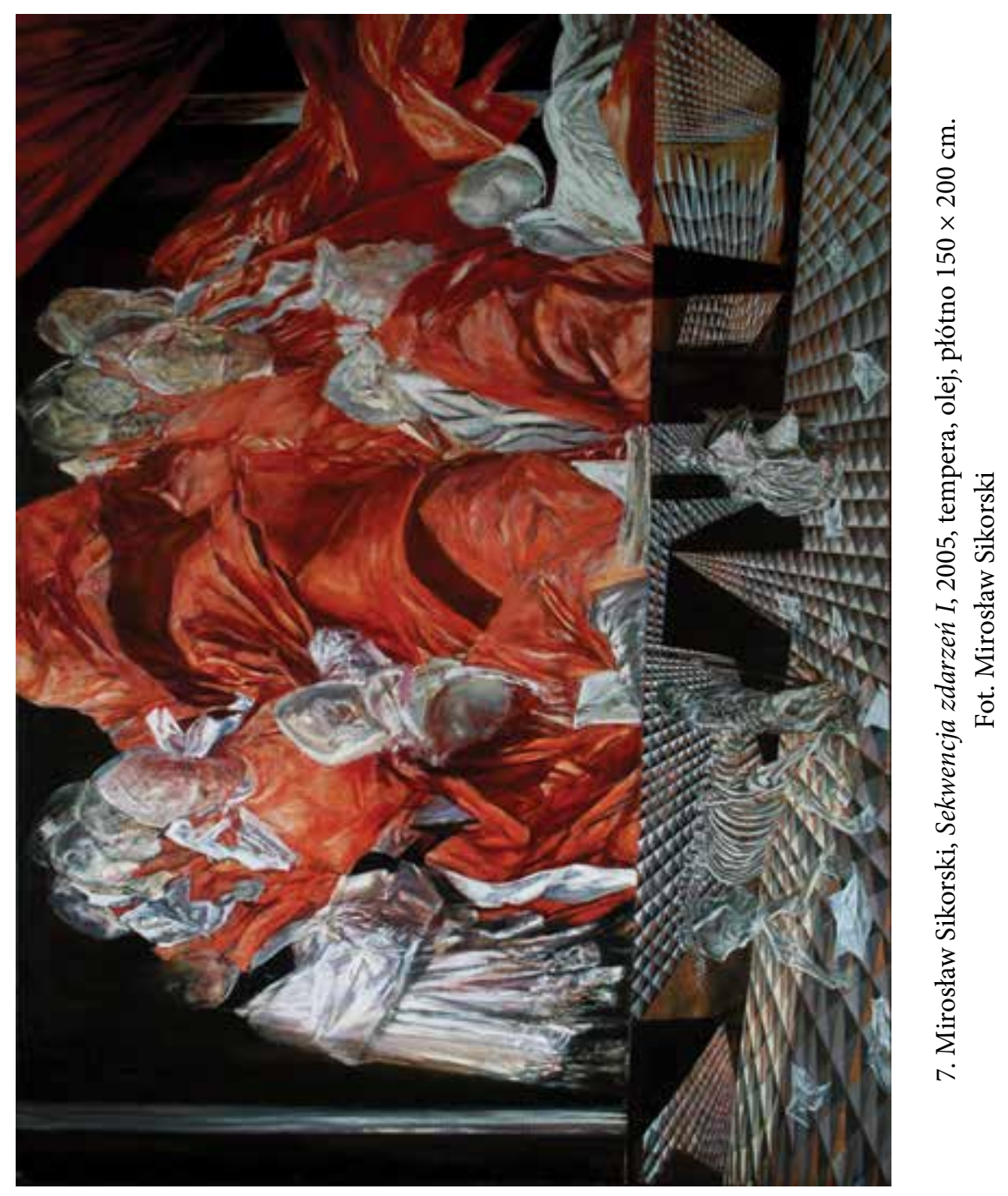






8. Grzegorz Bednarski, Modlitwa św. Katarzyny ze Sieny o zbawienie dusz wszystkich przy wsparciu św. Teresy z cyklu: Personifikacje, 2000, olej, płótno $100 \times 90 \mathrm{~cm}$.

Fot. ze zbiorów Grzegorza Bednarskiego 


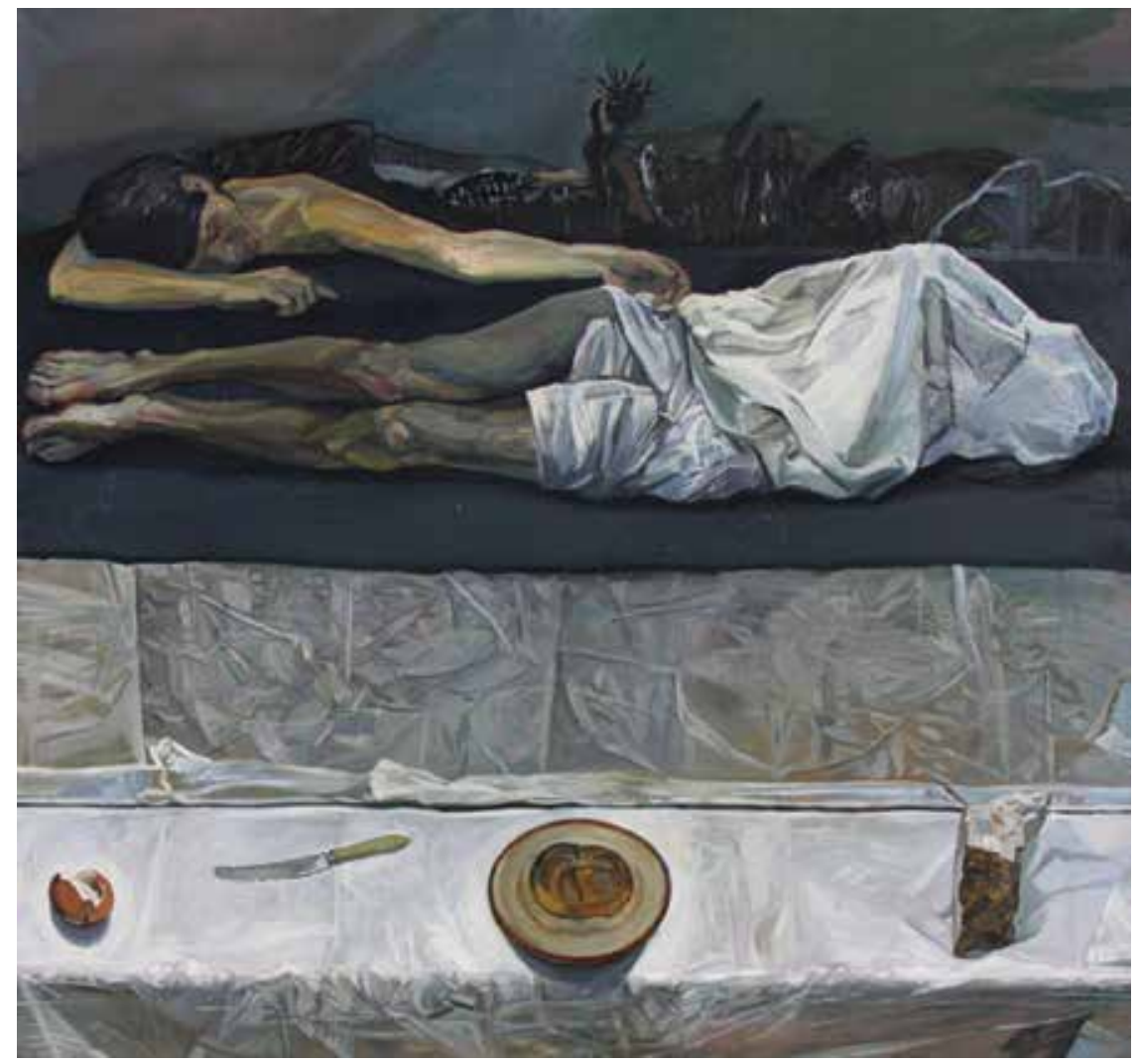

9. Wojciech Szybist, Pietà, 2012, olej, płótno $135 \times 165 \mathrm{~cm}$.

Fot. Wojciech Szybist 


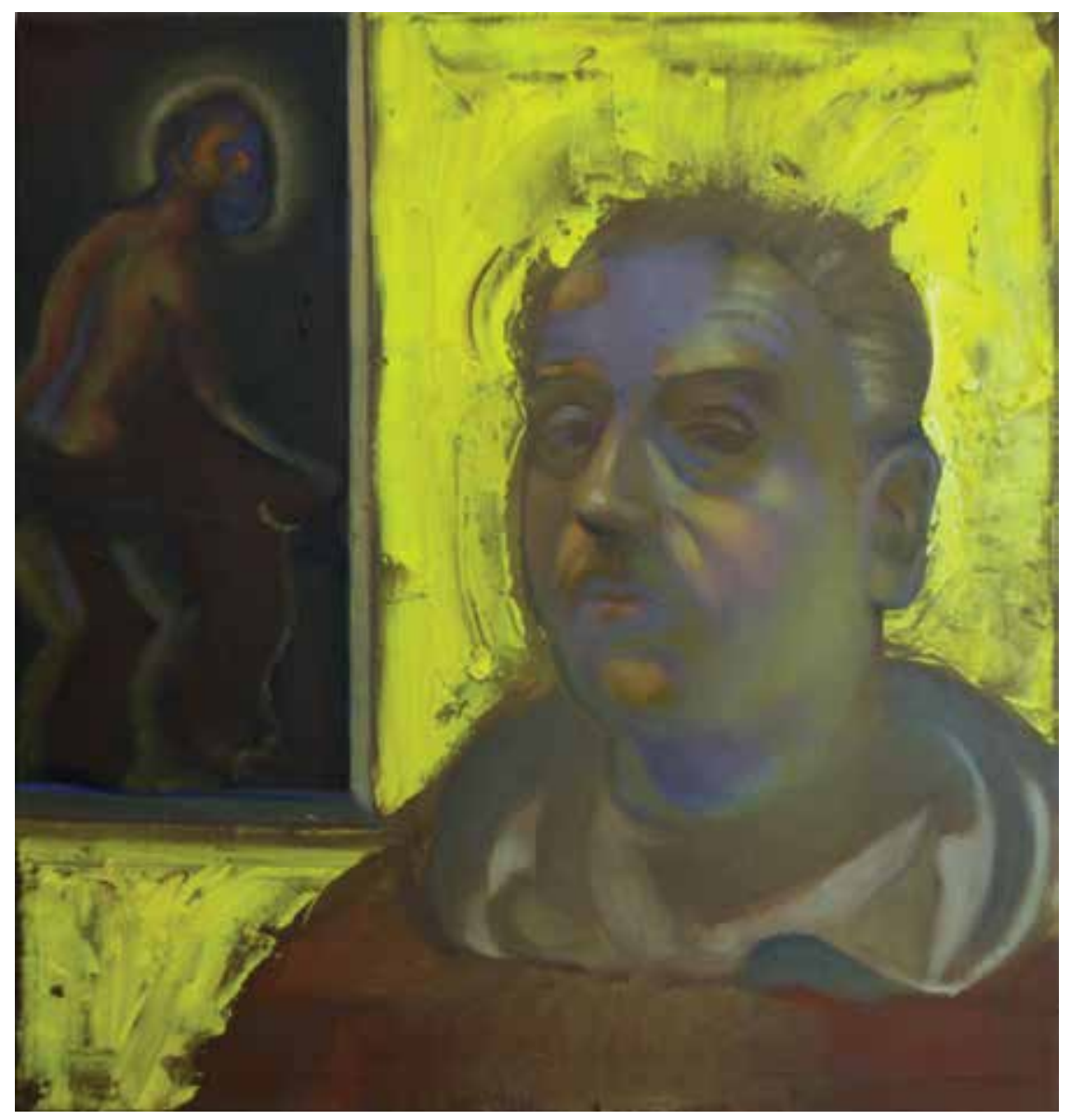

10. Janusz Matuszewski, Autoportret z Chrystusem, 2013-2014, olej, płótno $50 \times 46 \mathrm{~cm}$. Fot. Janusz Matuszewski 